\section{The unusual composition of nephelinites from Etinde: a new perspective on the origins of intraplate magmatic activity}

\section{SOPHIE BALDWIN, LINDA KIRSTEIN AND GODFREY FITTON}

University of Edinburgh

Presenting Author: Sophie.Baldwin@ed.ac.uk

Etinde is a Quaternary volcano, situated approximately midway along the Cameroon Volcanic Line (CVL), on the coast in Cameroon, West Africa (Figure 1). Etinde lavas are highly silicaundersaturated (nepheline-normative), ranging from rare olivine nephelinites, through olivine-free melanephlenites, to a felsic nosean leucitophyre. XRF analyses show that rocks from Etinde are highly enriched in incompatible trace elements (for example, Sr contents range up to $>7000 \mathrm{ppm}$ ). The lavas also have high concentrations of chlorine and sulphur (up to $\sim 4 \mathrm{wt} . \%$ each); however volatile enrichment in individual samples does not correspond with the enrichment shown in the incompatible trace elements. The unique composition of the magmas at Etinde leads to exotic mineral assemblages; the most evolved rocks are made up of nosean, leucite, nepheline, schorlomite and strontianmelilite [1] whilst assemblages in the intermediate rocks can contain up to $50 \%$ haüyne phenocrysts (Figure 2).

These studies form part of wider investigations into the causes of intraplate magmatic activity along the whole CVL. A new mechanism is required because many lines of evidence suggest that the commonly invoked mantle-plume explanation is not viable at the CVL. A possible alternative explanation proposed by Guimaraes et al. (2020) [2], invokes volatile enriched mantle flowing out from beneath Africa following supercontinent breakup. Channelised flow of enriched mantle at the base of the lithosphere could provide an alternative mechanism for the generation of intraplate magmatism in the CVL and elsewhere. Geochemical analysis of the Etinde rocks, including sulphur isotope compositions, help us to understand the origin of volatiles in intraplate magmas.

[1] Fitton, J.G. and Hughes, D.J. (1981), Mineralogical Magazine 44, 335, 261-264.

[2] Guimaraes, A.R. et al. (2020), EPSL 536, 116147.

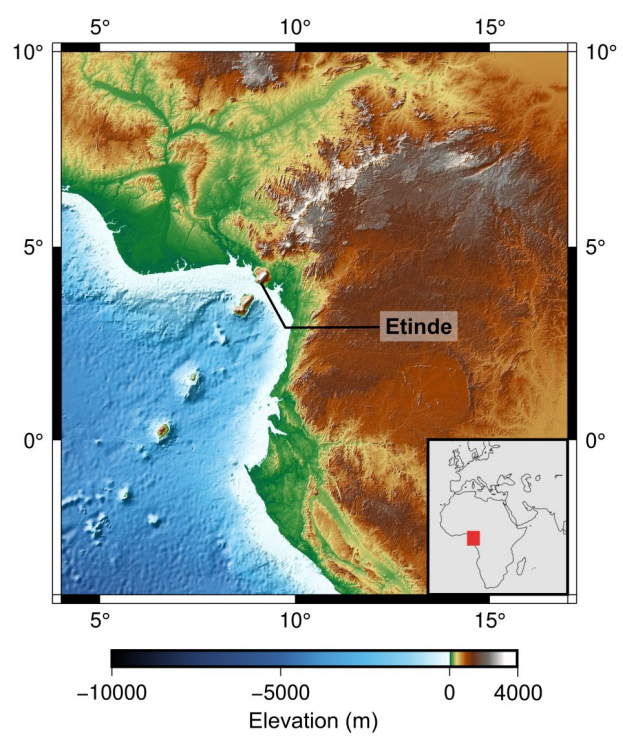

Figure 1: A map of the Cameroon Volcanic Line, coloured by elevation.

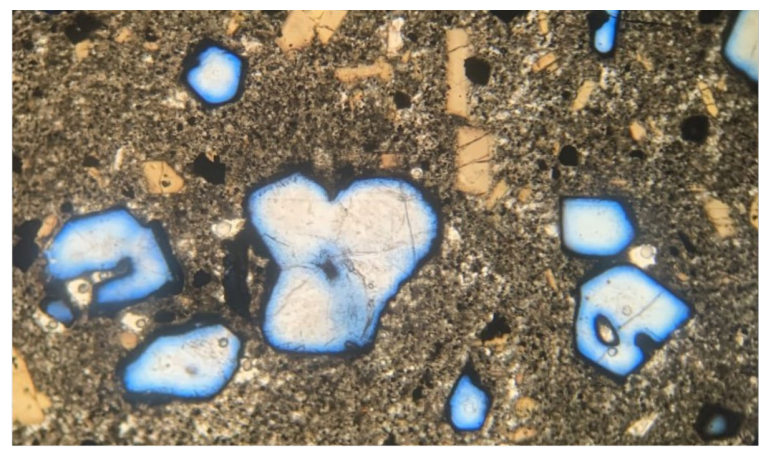

Figure 2: Haüyne phenocrysts (vivid blue) dominate the mineral assemblage in this rock from Etinde. View: $3 \mathrm{~mm}$ across, plane polarised light. 